\title{
Hepatitis B virus infection among pregnant women on antenatal visits: rapid tests or ELISA?
}

\author{
${ }^{* 1,2}$ Fowotade, A., ${ }^{2}$ Adetunji, S. O., ${ }^{2}$ Amadi, E., ${ }^{2}$ Ishola, I. O., and ${ }^{3}$ Omoruyi, E. C. \\ ${ }^{1}$ Clinical Virology Unit, Department of Medical Microbiology and Parasitology, College of Medicine, \\ University of Ibadan, Nigeria \\ ${ }^{2}$ Department of Medical Microbiology and Parasitology, University College Hospital, Ibadan, Nigeria \\ ${ }^{3}$ Institute of Child and Maternal Health, College of Medicine, University of Ibadan, Nigeria \\ *Correspondence to: temilabike@gmail.com
}

\begin{abstract}
:
Background: Hepatitis B virus (HBV) infection is a global public health challenge with over 360 million people infected worldwide, and is one of the leading causes of death worldwide. The hepatitis B surface antigen (HBSAg) is the most important marker for HBV screening, and HBSAg rapid screening test methods are the most widely used compared with the enzyme-linked immunosorbent assay (ELISA) and nucleic acid testing methods. The objectives of this study are to evaluate the comparative efficacy of rapid test kits and ELISA for HBV screening among pregnant women on antenatal visits and to screen for other HBV serological markers among HBsAg positive patients.

Methodology: This is a cross-sectional study of 172 pregnant women who were recruited consecutively on their first antenatal visit at the University College Hospital, Ibadan, Nigeria between November 2018 and February 2019. All participants were screened for HBsAg using both rapid immunochromatographic test (ICT) and ELISA techniques. HBsAg negative samples were further screened for anti-HBeAg/Ab, anti-HBcAg and anti-HBs by ELISA. Socio-demographic data of the participants were obtained using a semi-structured questionnaire, and data were analyzed using EPI INFO 7.2 statistical software.

Results: The prevalence rate of HBsAg among pregnant women in this study was $10.5 \%$ (18/172). The sensitivity, specificity, accuracy, positive predictive value (PPV) and the negative predictive value (NPV) of the rapid ICT kit were $72.2 \%, 97.4 \%, 94.8 \%, 76.5 \%$ and $96.8 \%$ respectively. Level of education, previous history of sexually transmitted infections (STIs) and previous positive HBV results were significantly associated with HBsAg seropositivity. Majority of the pregnant women (66.9\%) tested negative to all the serological markers. Conclusion: The low efficacy of rapid ICT kits compared to ELISA justifies the need to develop a safer antenatal screening strategy for HBV by combining the use of the less sensitive rapid screening techniques with the more sensitive ELISA method to limit vertical transmission of hepatitis B virus.
\end{abstract}

Keywords: Hepatitis B virus; Rapid ICT kits; ELISA; pregnant women

Received May 10, 2021; Revised May 25, 2021; Accepted May 26, 2021

Copyright 2021 AJCEM Open Access. This article is licensed and distributed under the terms of the Creative Commons Attrition 4.0 International License $<$ a rel="license" href="http://creativecommons.org/licenses/by/4.0/", which permits unrestricted use, distribution and reproduction in any medium, provided credit is given to the original author(s) and the source. Editor-in-Chief: Prof. S. S. Taiwo

\section{Infection par le virus de I'hépatite B chez les femmes enceintes en consultation prénatale: tests rapides ou ELISA?}

\author{
*1,2 Fowotade, A., ${ }^{2}$ Adetunji, S. O., ${ }^{2}$ Amadi, E., ${ }^{2}$ Ishola, I. O., et ${ }^{3}$ Omoruyi, E. C. \\ ${ }^{1}$ Unité de virologie clinique, Département de microbiologie médicale et de parasitologie, \\ Collège de médecine, Université d'Ibadan, Nigéria \\ ${ }^{2}$ Département de microbiologie médicale et de parasitologie, Hôpital universitaire, Ibadan, Nigéria \\ ${ }^{3}$ Institut de la santé infantile et maternelle, Collège de médecine, Université d'Ibadan, Nigéria \\ *Correspondance à: temilabike@gmail.com
}




\section{Abstrait:}

Contexte: L'infection par le virus de l'hépatite B (VHB) est un défi de santé publique mondial avec plus de 360 million de personnes infectées dans le monde et est l'une des principales causes de décès dans le monde. L'antigène de surface de l'hépatite B (HBSAg) est le marqueur le plus important pour le dépistage du VHB, et les méthodes de test de dépistage rapide HBSAg sont les plus largement utilisées par rapport aux méthodes de test immuno-enzymatique (ELISA) et d'acide nucléique. Les objectifs de cette étude sont d'évaluer l'efficacité comparative des kits de tests rapides et de I'ELISA pour le dépistage du VHB chez les femmes enceintes lors de consultations prénatales et de dépister d'autres marqueurs sérologiques du VHB chez les patients AgHBs positifs. Méthodologie: Il s'agit d'une étude transversale de 172 femmes enceintes qui ont été recrutées consécutivement lors de leur première visite prénatale à l'Hôpital Universitaire, Ibadan, Ibadan, Nigéria entre novembre 2018 et février 2019. Tous les participants ont été dépistés pour l'AgHBs en utilisant les deux tests immunochromatographiques rapides (TIC) et techniques ELISA. Les échantillons négatifs à l'AgHBs ont en outre été criblés pour l'anti-HBeAg/Ab, I'anti-HBcAg et l'anti-HBs par ELISA. Les données sociodémographiques des participants ont été obtenues à l'aide d'un questionnaire semi-structuré et les données ont été analysées à l'aide du logiciel statistique EPI INFO 7.2.

Résultats: Le taux de prévalence de l'HBSAg chez les femmes enceintes dans cette étude était de 10,5\% (18/172). La sensibilité, la spécificité, la précision, la valeur prédictive positive (VPP) et la valeur prédictive négative (VPN) du kit ICT rapide étaient respectivement de $72,2 \%, 97,4 \%, 94,8 \%, 76,5 \%$ et $96,8 \%$. Le niveau d'éducation, les antécédents d'infections sexuellement transmissibles (IST) et les résultats positifs antérieurs pour le VHB étaient significativement associés à la séropositivité de l'AgHBs. La majorité des femmes enceintes $(66,9 \%)$ ont été testées négatives pour tous les marqueurs sérologiques.

Conclusion: La faible efficacité des kits TIC rapides par rapport à I'ELISA justifie la nécessité de développer une stratégie de dépistage prénatal plus sûre du VHB en combinant l'utilisation des techniques de dépistage rapide moins sensibles avec la méthode ELISA plus sensible pour limiter la transmission verticale du virus de I'hépatite B.

Mots clés: virus de l'hépatite $B$; Kits TIC rapides; ELISA; femmes enceintes

\section{Introduction:}

Chronic hepatitis B virus (HBV) infection is the most common cause of liver cirrhosis and hepatocellular carcinoma (1). Vertical transmission of HBV is the most common cause of chronic HBV infection and is a public health concern in endemic regions, such as the Far East and Africa (2-5). The first detectable antigen in the course of HBV infections is the HBsAg whose presence often predates the appearance of symptoms in clinically ill patients. An identifiable viral core antigen (HBcAg) exists but does not circulate free in serum like HBsAg. A third antigen, the e antigen ( $\mathrm{HBeAg})$, is associated primarily with the core antigen in the internal structure of the virus, and can be found circulating in serum, frequently in complexes with immunoglobulin. The three antigens induce the production of equally distinct antibodies; HBsAb, HBcAb, and HBeAb respectively, in the course of non-chronic host infection $(6,7)$.

The risk of vertical transmission of HBV infection is highest at birth and studies have shown that majority of infants born to $\mathrm{HBsAg}$ positive mothers are seronegative at birth but seroconvert within the first 3 months postpartum (8-11). HBsAg and $\mathrm{HBeAg}$ seropositivity confers the highest risk for virus transmission with $85 \%$ to $100 \%$ of their offspring becoming infected, while $70 \%$ to $90 \%$ progress to become chronic carriers. Mothers with lower risk who are HBsAg-positive but HBeAg-nega- tive, presumably still transmit the virus to about $35 \%$ of their children in the absence of neonatal prophylaxis (12-15).

There are various laboratory techniques available for the detection of HBsAg including rapid tests, enzyme linked immuno-sorbent assay (ELISA) and nucleic acid amplification tests (NAATs). In lower-middle-income countries, including Nigeria, the rapid test kits are often widely employed for HBV screening. The comparative efficacy of ELISA and the rapid tests among the present cohort of pregnant women would provide a rationale for the use of either test in other high-risk populations.

\section{Materials and method:}

\section{Study setting, design and population}

This cross-sectional study was performed at the University College Hospital, Ibadan, Nigeria between November 2018 and February 2019. The 900-bedhospital is the first tertiary teaching healthcare facility in Nigeria and provides health care to a wide catchment of patients within the southwest region of Nigeria. One hundred and seventy-two (172) pregnant women, on their first antenatal visit were consecutively recruited into the study after obtaining their written informed consent. Administration of questionnaires was done to obtain the sociodemographic and clinical details of the participants. 


\section{Inclusion and exclusion criteria}

All pregnant women visiting the hospital antenatal clinic for the first time and who gave informed consent were included into this study while those on subsequent visits together with those who declined consent/or refused sample collection were excluded.

\section{Ethical clearance}

Ethical clearance was obtained from the joint Ethical Committee of the University of Ibadan and University College Hospital, Ibadan before the commencement of the study (UI/ $\mathrm{EC} / 18 / 0264)$.

\section{Specimen collection and storage}

Five milliliters of blood were drawn from each patient. Plasma was separated from the blood sample after collection and immediately stored at $-20^{\circ} \mathrm{C}$ in the freezer for hepatitis $B$ virus rapid and ELISA tests.

Rapid HBsAg ICT test and ELISA screening for HBsAg, HBeAg, HBeAb and HBCAb

All the samples were tested for hepatitis B surface antigen (HBSAg) using HBSAg rapid test kit (RTK) (LabACON, Hangzhou Biotest Biotech Company Limited, China). All the samples were further re-tested using enzymelinked immunosorbent assay (ELISA) kit for HBsAg (Dia.Pro, Milan, Italy) according to the instructions of the manufacturers. ELISA kits for $\mathrm{HBeAg}$, anti-HBeAb, anti-HBcAb and antiHBsAb (Dia.Pro, Milan, Italy) were used according to the instructions of the manufacturers to determine $\mathrm{HBeAg}$ and antibodies to $\mathrm{HBeAg}$, $\mathrm{HBCAg}$ and HBsAg.

The cutoff value for the HBsAg kit was determined according to the (mean negative control + mean positive control)/5. The positive and negative controls used were supplied by the manufacturer. Optical density (OD) was measured by an EMax Plus microplate reader (Molecular Devices), and the results were expressed as the cutoff index (COI). The COI was defined as the mean optical density difference between reactive control and non-reactive control $1.0(\mathrm{RC}-\mathrm{NRC}=1.0)$. HBsAg detection was considered positive for a COI value $\geq 1$. The performance of the kits was evaluated in terms of sensitivity, specificity, and overall agreement with the $95 \%$ confidence intervals ( $95 \% \mathrm{CI}$ ) according to the CLSI EP12-A guidelines (16).

\section{Data analysis}

Data were collected and entered into Excel spreadsheet and analyzed using EPIINFO 7.2 statistical software. Association between socio-demographic and clinical features, and $\mathrm{HBsAg}$ status of the pregnant women was evaluated using the Chi-square statistic at 95\% confidence interval, and statistical significance value of 0.05. Sensitivity, specificity, accuracy, positive and negative predictive values were calculated using the formulae below;

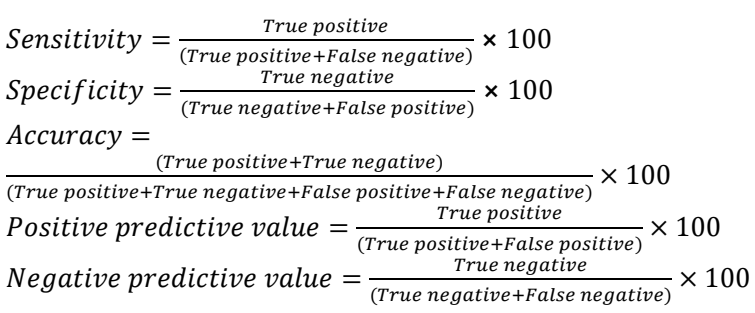

\section{Results:}

A total of 172 pregnant women participated in this study with $44.2 \%$ below the age of 30 years while $55.8 \%$ were $\geq 30$ years of age. One hundred and sixty-nine (98.3\%) were married and three (1.7\%) were single. Majority $(94.2 \%)$ had post secondary school education while the highest educational qualification for others $(5.8 \%)$ was secondary school certificate examination (SSCE). Majority $(87.8 \%)$ of the participants were employed while $12.2 \%$ were unemployed. Primigravid women constituted a third of the study participants $(33.1 \%)$ while the other two-third were multigravida women (Table 1).

The prevalence rate of HBsAg among pregnant women in this study was $10.5 \%$ by ELISA test (18/172). The distribution of HBV infection (HBSAg positive) varied according to the socio-demographic characteristics as shown in Table 1. Pregnant women below the age of 30 years $(11.8 \%)$ had higher prevalence rate compared to those aged above 30 years $(9.4 \%)$ but the difference in the rates was not statistically significant $(p=0.560)$. All the HBSAg positive cases were among the married pregnant women. Educational level and HBV infection had a significant relationship $\left(X^{2}=\right.$ $4.324 ; p=0.038$ ) with those with secondary education having a higher prevalence of $30 \%$ compared to $9.3 \%$ in those with post secondary education. The unemployed (14.3\%) and those pregnant for the first time $(12.3 \%)$ had a higher rate of $\mathrm{HBV}$ infection compared to the employed and multiparous participants respectively although there were no statistically significant differences in the rates $(p>0.05)$.

There was observed a significant relationship between $\mathrm{HBV}$ infection and previous HBV results $\left(X^{2}=15.259 ; p=0.000\right)$ as well as HBV infection with previous history of sexually transmitted infections (STIs) $\left(X^{2}=6.545 ; p=\right.$ 
0.011). Meanwhile, there was no statistically significant association between $\mathrm{HBV}$ infection and other correlates such as history of HBV vaccination, previous HBV screening, scarification as a child and as an adult, history of contact with HBV patient, history of surgical and dental procedure, circumcision as an adult and HIV status (Table 2).

The total number of HBSAg positive samples using the rapid test kits was 17 (9.9\%) while the ELISA method identified 18 $(10.5 \%)$ positive samples. Five of the 18 ELISA HBsAg positive samples tested negative with the rapid kits while 4 of the 17 RTK positive samples tested negative with the ELISA test as shown in Table 3. The calculated sensitivity was $72.2 \%$, specificity $97.4 \%$, accuracy $94.8 \%$, positive predictive value (PPV) $76.5 \%$ and the negative predictive value (NPV) was $96.8 \%$.

All the 154 HBsAg ELISA negative samples were further tested for other HBV serological markers. Thirty-seven (24.0\%) tested positive to anti-HBc only, $3(1.9 \%)$ tested positive to anti-HBe only, $11(7.1 \%)$ tested positive to both anti-HBc and anti-HBe. None was positive to $\mathrm{HBeAg}$ and $\mathrm{HBsAb}$ (Table 4).

Table 1: Frequency of HBsAg distribution with respect to socio-demographic characteristics of pregnant women attending University College Hospital Ibadan, Nigeria

\begin{tabular}{|c|c|c|c|c|c|c|}
\hline \multirow{2}{*}{ Variables } & \multirow[t]{2}{*}{ Groups } & \multirow{2}{*}{$\begin{array}{l}\text { No tested (\%) } \\
\quad(n=172)\end{array}$} & \multicolumn{2}{|c|}{ HBsAg } & \multirow[t]{2}{*}{$X^{2}$} & \multirow[t]{2}{*}{ p-value } \\
\hline & & & Positive (\%) & Negative (\%) & & \\
\hline \multirow[t]{2}{*}{ Age (years) } & $<30$ & $76(44.2)$ & $9(11.8)$ & $67(88.2)$ & 0.276 & 0.560 \\
\hline & 30 and above & $96(55.8)$ & $9(9.4)$ & $87(90.6)$ & & \\
\hline Marital status & Single & $3(1.7)$ & $0(0)$ & $3(100)$ & 0.357 & 0.550 \\
\hline \multirow[t]{2}{*}{ Educational level } & Secondary & $10(5.8)$ & $3(30.0)$ & $7(70.0)$ & 4.324 & $0.038 *$ \\
\hline & Post-secondary & $162(94.2)$ & $15(9.3)$ & $147(89.7)$ & & \\
\hline \multirow[t]{2}{*}{ Occupation } & Employed & $151(87.8)$ & $15(9.9)$ & $136(89.1)$ & 0.373 & 0.542 \\
\hline & Unemployed & $21(12.2)$ & $3(14.3)$ & $18(85.7)$ & & \\
\hline Parity & Multigravid & 115 (66.9) & $11(9.6)$ & $104(89.4)$ & & \\
\hline
\end{tabular}

Table 2: Frequency of HBsAg distribution with respect to clinical characteristics of pregnant women attending University College Hospital, Ibadan, Nigeria

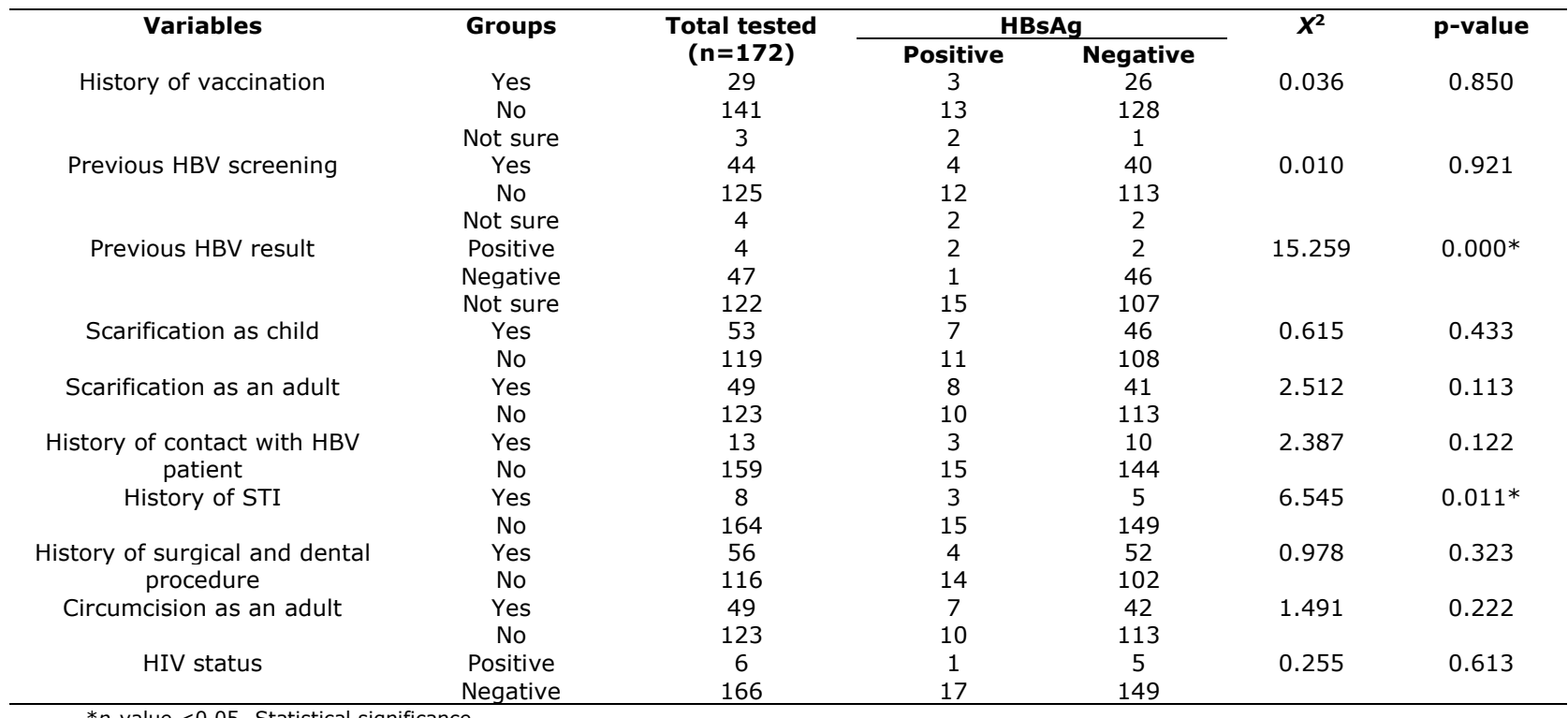


Table 3: Comparative efficacy of Rapid Test Kits and ELISA in HBsAg screening

\begin{tabular}{|c|c|c|c|c|c|c|c|c|c|c|}
\hline \multirow{2}{*}{$\begin{array}{l}\text { Rapid } \\
\text { kits }\end{array}$} & \multicolumn{2}{|c|}{ ELISA } & \multirow{2}{*}{$\begin{array}{l}\text { Total } \\
(\%)\end{array}$} & \multirow{2}{*}{$\begin{array}{c}\text { Sensitivity } \\
(\%)\end{array}$} & \multirow{2}{*}{$\begin{array}{c}\text { Specificity } \\
(\%)\end{array}$} & \multirow{2}{*}{$\begin{array}{c}\text { Accuracy } \\
(\%)\end{array}$} & \multirow{2}{*}{$\begin{array}{l}\text { PPV } \\
\text { (\%) }\end{array}$} & \multirow{2}{*}{$\begin{array}{l}\text { NPV } \\
(\%)\end{array}$} & \multirow[t]{2}{*}{$x^{2}$} & \multirow{2}{*}{$\begin{array}{c}\text { p- } \\
\text { value }\end{array}$} \\
\hline & $\begin{array}{c}\text { Positive } \\
(\%)\end{array}$ & $\begin{array}{c}\text { Negative } \\
(\%)\end{array}$ & & & & & & & & \\
\hline Positive & $\begin{array}{c}13 \\
(72.2)\end{array}$ & $\begin{array}{c}4 \\
(2.6)\end{array}$ & $\begin{array}{c}17 \\
(9.9)\end{array}$ & 72.2 & 97.4 & 94.8 & 76.5 & 96.8 & 87.71 & $0.00 *$ \\
\hline Negative & $\begin{array}{c}5 \\
(27.8)\end{array}$ & $\begin{array}{c}150 \\
(97.4)\end{array}$ & $\begin{array}{c}155 \\
(90.1)\end{array}$ & & & & & & & \\
\hline Total & $\begin{array}{c}18 \\
(100)\end{array}$ & $\begin{array}{c}154 \\
(100)\end{array}$ & $\begin{array}{c}172 \\
(100)\end{array}$ & & & & & & & \\
\hline
\end{tabular}

Table 4: Presence of other HBV markers among HBsAg negative study participants

\begin{tabular}{|c|c|c|c|}
\hline Profile & Other HBV markers & Frequency (\%) & Virological explanation \\
\hline A1 & Anti-HBc only & $37(24.0)$ & Resolved or occult HBV infection \\
\hline A2 & Anti-HBe only & $3(1.9)$ & Resolving HBV infection \\
\hline A3 & Anti-HBc and anti-HBe & $11(7.1)$ & Resolving HBV infection \\
\hline A4 & No additional marker & $103(66.9)$ & HBV infection susceptible \\
\hline Total & & $154(100)$ & \\
\hline
\end{tabular}

\section{Discussion:}

To achieve the vision of the Global Health Sector Strategy (GHSS) to end HBV infection by 2030, accurate detection of HBV infection is very important (17). This is of greater importance among pregnant women who carry the potential risk of vertical transmission. The seroprevalence of HBSAg among pregnant women reported in this study was $10.5 \%$. The finding from the current study is similar to the reports from a 13-year metaanalytical study which documented $11.5 \%$ HBSAg seroprevalence (18). Similar observations among a cohort of pregnant women have also reported HBsAg seroprevalence range of $5.4-12 \%(19-22)$. A study among pregnant women from Mali has also reported a seroprevalence of $10.5 \%$ (23), while $9.2 \%$ was observed in Gambia (24) and $17.3 \%$ in Burkina Faso (25). Contrastingly lower levels have been reported from other parts of Africa including; $2.4 \%$ in Rwanda, $4.9 \%$ in Uganda (26) and $5.6 \%$ in Sudan (7).

The level of endemicity of HBV infection in these regions contribute to the prevalence rate observed among the cohort studied. Several studies among other populations within Nigeria have reported HBSAg prevalence ranges that vary between 5 and $18 \%(28-30)$. All these studies affirm the hyper-endemicity status of Nigeria and underscore the need for an efficient screening method for HBV infection particularly among pregnant women. The lower HBSAg seroprevalence rate of $2 \%$ reported from Western Europe and United States of America might be due to increased access to vaccination services for HBV as well as better infection prevention and control practices towards hepatitis B prevention (31).

The sensitivity of the rapid test used in this study was $72.2 \%$ with an accuracy of $94.8 \%$ compared with ELISA. This is lower than $90 \%$ sensitivity and $99.9 \%$ accuracy reported in Bangladesh (32). Previous authors have also reported higher sensitivity for rapid test kits; $97 \%$ (33) and $93.4 \%$ (34) from two different studies in India. A lower sensitivity of $51.6 \%$ sensitivity was reported in South East, Nigeria (35). The rapid test kits are widely used for screening for hepatitis B infection in Nigeria hence the need to assess their efficacy particularly among important risk groups. A false negative HBsAg result among pregnant women pre-empts the need for administration of prophylactic hepatitis B immunoglobulin postdelivery. This increases the risk of development of chronic liver disease among in adulthood $(36,37)$. Although, ELISA offers a more reliable option for the detection of HBsAg, the feasibility of its routine utilization for screening purposes is reduced because of its higher cost, requirement for additional equipment as well as a longer turn-around-time.

There was no significant association between HBV infection and socio-demographic 
characteristics such as age, marital status, parity and occupation. There was however a significant association with level of education of the participants $\left(X^{2}=4.324 ; p=0.038\right)$; those with secondary education had a higher prevalence rate compared with those with postsecondary education. Donbraye et al., (20) reported a similar observation with $59.3 \% \mathrm{HBSAg}$ seroprevalence rate among those with only secondary education. This suggests that education informs risk taking behavior that might impart on hepatitis B virus infectivity. This is however different from the report of Opaleye et al., (38) where the more educated pregnant women had a higher rate of HBSAg prevalence, thus suggesting possibility of other confounding factors.

Previous positive HBV results and past history of other sexually transmitted infections (STIs) were significantly associated with HBSAg seropositivity. Previous history of STI suggests possible co-infection with HBV due to similarity in mode of transmission. Earlier studies reported similar association as observed in the current study $(39,40)$. Other possible risk factors for HBV infection such as history of HBV vaccination, previous HBV screening, scarification as a child and as an adult, history of contact with HBV patient, history of surgical and dental procedure, circumcision as an adult and HIV status were not significantly associated with HBSAg seropositivity among the pregnant women, which is similar to earlier reports among the same study population (3941). This finding however contrasts report by Rukunuzzaman and Afroza (43) in their study among a different study population.

Thirty-seven (24\%) of the HBsAg negative pregnant women were positive for anti$\mathrm{HBC}$ only, while $3(1.9 \%)$ had anti-HBe only, and $11(7.1 \%)$ had both anti-HBc and anti$\mathrm{HBe}$. The $24 \%$ anti-HBc in this study is far higher than previous findings among pregnant women in other reports; $1.5 \%$ reported by Zahn et al., (44) among pregnant women, $5.4 \%$ by Adetunji et al., (45) among apparently healthy individuals and $17 \%$ by Oluyinka et al., (46) among blood donors in Ile-Ife. HBSAg negative pregnant women with anti-HBc often have low hepatitis $B$ viral load but remain potentially infectious (47-49). The detection of anti-HBe in some pregnant women in this study signifies the resolution of the $\mathrm{HBV}$ infection while seropositivity to both anti-HBc and antiHBe markers connotes convalescent stage.

All the HBsAg seronegative pregnant women also tested negative for $\mathrm{HBeAg}$ and $\mathrm{HBsAb}$ thus confirming that although none of them was in the active replication phase of
HBV infection but all were susceptible to hepatitis $B$ infection. This finding is not surprising as majority of the participants were unvaccinated against hepatitis $B$ virus.

\section{Conclusion:}

Although the HBsAg seropositivity is high among the study population, the efficacy of rapid test kits compared to ELISA is low. ELISA is recommended for HBV screening among pregnant women to prevent falsenegative results. There is need to develop a safer antenatal screening strategy for HBV possibly by combining the use of the less sensitive rapid screening techniques with the more sensitive ELISA method to limit vertical transmission of hepatitis B virus. The high number of unvaccinated HBV-susceptible pregnant women justifies the need for increased advocacy for HBV vaccination.

\section{References:}

1. Lee, W. M. Hepatitis B virus infection. New Engl J Med. 1997; 337(24):1733-1745.

2. Ott, J. J., Stevens, G. A., and Wiersman, G. A. The risk of perinatal hepatitis $B$ virus transmission: hepatitis $B(\mathrm{HBeAg})$ prevalence estimates for all world regions. BMC Infect Dis. 2012; 12:131.

3. Arevalo, J. A. Hepatitis B in pregnancy. Western J Med. 1989;150(6):668-674.

4. Beasley, R. P., Trepo, C., and Stevens, C. E. The e antigen and vertical transmission of hepatitis $B$ surface antigen. Am J Epidemiol. 1977;105(2):9498.

5. Beasley, R. P., and Hwang, L. Y. Postnatal infectivity of hepatitis $B$ surface antigen carrier mother. J Infect Dis. 1983;147(2):185-190.

6. World Health Organization Factsheet on Hepatitis B2019. Geneva: WHO, 2019: https://www. who.int/news-room/fact-sheets/detail/hepatitis-b [Retrieved September, 2020]

7. Centre for Disease Control and Prevention, Division of Viral Hepatitis: Hepatitis B Information 2020.https://www.cdc.gov/hepatitis/hbv/index.htm [Retrieved September, 2020]

8. Schweitzer, I. L., Wing, A., McPeak, C., et al. Hepatitis and hepatitis-associated antigen in 56 mother-infant pairs. JAMA. 1972; 220:1092

9. Okada, K., Yamada, T., Miyakawa, Y., et al. Hepatitis B surface antigen in the serum of infants after delivery from asymptomatic carrier mothers. J Pediatr.1975; 87:360

10. Gerety, R. J., and Schweitzer, I. L. Viral hepatitis type B during pregnancy, the neonatal period, and infancy. J Pediatr.1977; 90:368

11. Lee, A. K. Y., Ip, H. M. H., and Wong, V. C. W. Mechanisms of maternal-fetal transmission of hepatitis B virus. J Infect Dis.1978; 138:668

12. Okada, K., Kamiyama, I., Inomata, M., et al. The e antigen and anti-e in the serum of asymptomatic carrier mothers as indicators of positive and negative transmission of hepatitis $B$ virus to their infants. N Engl J Med.1976; 294:746

13. Beasley, R. P., Trepo, C., Stevens, C. E., et al. The e antigen and vertical transmission of hepatitis $B$ surface antigen. Am J Epidemiol.1977; 105:94 
14. Stevens, C. E., Toy, P. T., Tong, M. J., et al. Perinatal hepatitis $B$ virus transmission in the United States: Prevention by passive-active immunization. JAMA.1985; 253:1740

15. Biswas, S. C., Gupta, I., Ganguly, N. K., et al. Prevalence of hepatitis B surface antigen in pregnant mothers and its perinatal transmission. Trans Roy Soc Trop Med Hyg.1989; 83:698

16. Clinical and Laboratory Standards Institute (CLSI) User Protocol for Evaluation of Qualitative Test Performance; Approved Guideline - Second Edition. CLSI Document EP12-A2. Wayne, PA: Clinical and Laboratory Standards Institute; 2008

17. Yasir, W., Masood, S., Zubia, J., and Muzammil, H. N. Hepatitis elimination by 2030: progress and challenges. World J Gastroenterol. 2018; 24(44): 4959-4961

18. Musa, B. M., Bussell, S., Borodo, M. M., et al. Prevalence of hepatitis $B$ virus infection in Nigeria, 2000-2013: a systematic review and metaanalysis. Niger J Clin Pract. 2015; 18: 163-172.

19. Umolu, P. I., Okoror, L. E., and Orhue, P. Human Immunodeficiency Virus (HIV) seropositivity and hepatitis B surface antigenemia (HBsAg) among blood donors in Benin City, Edo state, Nigeria. Afr J HIth Sci. 2005;5(1):5558.

20. Donbraye, E., Adetunji, S. O., Ekong, M. J., Olaniran, O. B., and Adetunji, B. I. Burden of HBV infection among pregnant women in a low-income city of Ibadan, Nigeria. World J Med Sci. 2019; 16(4):170-174

21. Anaedobe, C., Fowotade, A., Omoruyi, E. C., and Bakare, R. A. Prevalence, socio-demographic and sexual behavioural risk factors for hepatitis $B$ virus infection among pregnant women in Southwestern Nigeria. Sex Trans Infect. 2017; 93 (Suppl 2): A108-A109

22. Ophori, E. A., Wagbasoma, A., and Atunumu, O. Seroprevalence of hepatitis B among Pregnant Women Attending antenatal at Central Hospital, Ward. Nig J Microbiol. 2004; 18:1-2.

23. MacLean, B., Hess, R. F., Bonvillain, E., Kamate, J., Dao, D., Cosimano, A., and Hoy, S. Seroprevalence of hepatitis B surface antigen among pregnant women attending the Hospital for Women \& children in Koutiala, Mali. S Afr Med J. 2011; 102(1):47-49.

24. Bittaye, M., Idoko, P., Ekele, B. A., Obed, S. A., and Nyan, O. Hepatitis B virus sero-prevalence amongst pregnant women in the Gambia. BMC Infect Dis. 2019; 19:259-267

25. Collenberg, E., Ouedraogo, T., Ganame, J., et al. Seroprevalence of six different viruses among pregnant women and blood donors in rural and urban Burkina Faso: a comparative analysis. J Med Virol. 2006; 78: 683-692.

26. Pirillo, M. F., Bassani, L., Germinario, E. A. P., et al. Seroprevalence of hepatitis $B$ and $C$ viruses among HIV infected pregnant women in Uganda and Rwanda. J Med Virol. 2007; 79: 1797-1801.

27. Elsheikh, R. M., Daak, A. A., Elsheikh, M. A., Karsany, M. S., and Adam, I. Hepatitis B virus and hepatitis $C$ virus in pregnant Sudanese women. Virol J. 2007; 4: 104.29.

28. Tula, M. Y., and Iyoha, O. A. Cross-sectional study on the sero-prevalence of hepatitis B surface antigen (HBsAg) among apparently healthy students of a tertiary institution in north-eastern Nigeria. Int J Trop Dis HIth. 2015;7(3):102-108.

29. Adetunji, S. O., Donbraye, E., Adetunji, B. I., and Olaniran, B. O. Viral Hepatitis B Screening among Asymptomatic Patients of Liver Pathology in a Secondary Health-care Facility in Nigeria. Int Trop Dis HIth.2020;41(4): 9-16

30. Redd, J. T., Baumbach, J., Kohn, W., Nainan, O., Khristova, M., and Williams, I. Patient to patient transmission of hepatitis B virus associated with oral surgery. J Infect Dis. 2007; 195: 1311-1314.

31. Donbraye, E., Japhet, M. O., Adesina, A. O., and Abayomi, O. A. Prevalence of asymptomatic hepatitis B virus surface antigenemia in children in Ilesha, Osun state, South-Western Nigeria. Afri J Microbiol Res.2014; 8(23): 2329-2331

32. Asaduzzaman, M., Milon, A. S., Juliana, F. M., Islam, M. J., and Kabir, M. S. Comparison Between Rapid ICT and ELISA Tests for The Detection Of $\mathrm{HBsAg}$; And Screening Of Hepatitis B Infection In Apparently Healthy Bangladeshi Outbound Staff. Int J Engineer Sci.2018;7(9): 34-39

33. Irwig, L., Bossuyt, P., Glasziou, P., Gatsonis, C., and Lijmer, J. Designing studies to ensure that estimates of test accuracy are transferable. Br Med J. $2002 ; 324: 669-671$.

34. Kaur, H., Dhanao, J., and Oberoi, A. Evaluation of rapid kits for detection of $\mathrm{HIV}, \mathrm{HBsAg}$ and $\mathrm{HCV}$ infections. Indian J Med Sci. 2000; 54:432-434.

35. Ezeilo, M. C., Engwa, G. A., Iroha, R. I., and Odimegwu, D. C. Seroprevalence and Associated Risk Factors of Hepatitis B Virus Infection Among Children in Enugu Metropolis. Virology: Research and Treatment. 2018; 9: 1-7

36. Agyeman, A. A., and Ofori-Asenso, R. Prevalence of HIV and hepatitis B co-infection in Ghana: a systematic review and meta-analysis. AIDS Res Ther. 2016; 13: 23.

37. Ott, J.J., Stevens, G. A., Groeger, J., et al. Global epidemiology of hepatitis $B$ virus infection: new estimates of age-specific $\mathrm{HBsAg}$ seroprevalence and endemicity. Vaccine. 2012; 30: 2212-2219.

38. Opaleye, O. O., Salami, S., Funmilayo, F., Olowe, O. A., and Ojurongbe, O. Seroprevalence of Hepatitis B Surface Antigen and Antibody among Pregnant Women Attending a Tertiary Health Institution in Southwestern Nigeria. IOSR J Dent Med Sci. 2014; 13(3): 67-71.

39. Rabiu, K. A., Akinola, O. I., Adewunmi, A. A., Omololu, O. M., and Ojo, T. O. Risk factors for hepatitis B virus infection among pregnant women in Lagos, Nigeria. Acta Obstetricia et Gynecologica. 2010; 89: 1024-1028

40. Obi, S. N., Onah, H. E., and Ezugwu, F. O. Risk factors for hepatitis $B$ infection during pregnancy in a Nigerian obstetric population. J Obstet Gynaecol. 2006; 26: 770772.

41. Akani, C. I. Ojule, A. C., Opurum, A. C., and Ejimele, A. A Sero-prevalence of hepatitis B surface antigen (HBsAg) in pregnant women in Port Harcourt, Nigeria. Niger Postgrad Med J. 2005; 12: 266-270.

42. Dienstag, J. L. Hepatitis B virus infection. N Engl J Med. 2008; 359: 1486-1500.

43. Rukunuzzaman, M., and Afroza, A. Risk factors of hepatitis $B$ virus infection in children. Mymensingh Med J. 2011; 20: 700-708.

44. Zahn, A., Li, C., Danso, K., Candotti, D., Owusu-Ofori, S., Temple, J., and Allain, J. P. Molecular Characterization of Occult Hepatitis B Virus in Genotype E-Infected Subjects. J Gen Virol. 2008;89(2): 409-418.

45. Adetunji, S. O., Donbraye, E., Alawode-Obabiyi, L., and Akinniyi, O. Serological profile of HBV infection among apparently healthy hospital attendees. Journal of Immunoassay and Immunochemistry. 2018;40(3): 237249.

46. Opaleye, O. O., Tong, H. V., Bui Tien, S., et al. Occult Hepatitis B Virus Infection in Nigerian Blood Donors and Hepatitis B Virus Transmission Risks. PLoS One. 2015; 10 (7): e0131912.

47. Manzini, P., Girotto, M., Borsotti, R., et al. Italian Blood Donors with anti-HBc and Occult Hepatitis B Virus Infection. Haematologica. 2007;92: 1664-1670.

48. Satake, M., Taira, R., Yugi, H., Hino, S., Kanemitsu, K. Ikeda, H., and Tadokoro, K. Infectivity of Blood Components with Low Hepatitis B Virus DNA Levels Identified in a Lookback Program. Transfusion. 2007;47(issue-7):1197-1205.

49. Bouike, Y., Imoto, S., Mabuchi, O., et al. Infectivity of HBV DNA Positive Donations Identified in Look-Back Studies in Hyogo-Prefecture, Japan. Transfus Med. 2011; 21: 107115. 